\title{
A Brief Analysis of Cultivation of Applied Talents of Radio \& TV Editing
}

\author{
Tu Man \\ Nanchang Institute of Technology, Nanchang City, Jiangxi Province, 330044
}

Keywords: Radio \& TV editing, Applied talents, Cultivation strategy.

\begin{abstract}
With the rapid development of the society, various industries in our country have had unprecedentedly high-speed development. In particular, China's mass media industry has gained the revolutionary rapid development. With the rapid development of related industries, the lack of relevant professionals is also increasingly prominent. The major of radio \& TV editing mainly cultivates the mass media talents. In the curriculum teaching of the media major in domestic higher education, theoretical teaching has always been emphasized; however, the practical teaching is not that satisfactory. The applied talents of radio \& TV editing are insufficient. In order to adapt to China's economic and social development, the major of radio \& TV editing should strengthen the cultivation of applied talents, deepen the reform, make a comprehensive adjustment to it with the spirit of innovation and make researches according to the characteristics of the majors. In the process of cultivating the applied talents, give more considerations to the demands of various aspects in the society. The future talent cultivation orientations of the universities should not merely focus on the theoretical knowledge, but also strengthen the cultivation of practical ability, so as to make university students accomplish tasks with east in the social career of radio \& TV industry.
\end{abstract}

\section{Introduction}

As early as the last century, the major of radio \& TV editing has gained rapid development. Radio \& TV editing belongs to a new discipline. In the primary stage of development, related industries have had rapid development. Many colleges and universities have widely opened the major of radio \& TV editing and meanwhile opened related undergraduate education, which shows that colleges and universities have attached great importance to the major of radio \& TV editing. In order to meet the needs of modern society of the radio \& TV editing talents, the professional training model of the radio \& TV editing has to be studied. Improve and innovate the education and teaching mode of the radio \& TV editing major, give full play to the huge role of radio \& TV editing in the field of China's media industry.

\section{Positioning Evidence of Construction of Applied Talent Cultivation Mode of Radio \& TV Editing}

Under the guidance of the mature educational ideas and comprehensive educational theories, the preliminary mode of personnel training can be constructed. At the same time, in order to realize the requirements of standardized cultivation of professional talents of radio \& TV editing, it is necessary to build a rational mode of applied talent cultivation, formulate the training procedures, training level, training specifications and training methods relatively consistent with the actual requirements of the community and make them gradually form self-improvement. Therefore, the pattern of personnel training should have an accurate basis for positioning, so as to ensure that the radio \& TV editing industry can have stable and sustainable development and guarantee the quality of the efficiently output talents. In the construction and continuous improvement of the applied talent training model of the radio \& TV editing, the applied talent cultivation that the social development requires should be taken as the important basis for positioning, which should be placed in the priority of the education of curriculum teaching of universities. Give correct 
ideological and political education to the radio \& TV editing talents, enable them to set up the correct world outlook and practice outlook. And position the professional cultivation orientation of the universities on this basis. The radio \& TV editing major is the important manifestation of soft culture; radio and television affect people's lives and work. Workers in the radio and television industry assume important tasks. By using the radio and television industry, the Party's values, concepts and the spirit of mass culture can be conveyed. In terms of the current social development background and realistic conditions, colleges and universities should fully integrate the characteristics of the development of the times in the training of applied talents. In the course of cultivating the applied talents of radio \& TV editing, the essence of society and the spirit of the times are fully integrated into the teaching materials. The future employment of students must conform to the laws of art and the laws of the market. The main goal of higher education in our country is to provide qualified senior talents for the society, so the senior talents in our country must have the spirit of innovation and practical ability. Our universities should regard the cultivation of senior talents as the main direction of professional development.

\section{Characteristics Research of the Cultivation Mode Construction of Applied Talents of radio \& TV editing}

In order to meet the needs of the rapid development of the society, the cultivation of China's higher education of the new applied talents should gradually explore the training model in line with the national conditions in the aspects of theoretical curriculum teaching and practical curriculum teaching. There is no doubt that China is still in the initial stage of the development of socialism; China's development in various periods has their own characteristics of China. The applied talents of radio \& TV editing are in urgent need in the process of social development. Therefore, the cultivation of the professional talents must accurately and dialectically deal with the relationship between professional theory and professional application. For the training of the applied talents of radio \& TV editing, focus on "one specialty and multiple abilities". Do not use the framework to limit the development of students. While teaching students theoretical knowledge, strengthen quality education and encourage students to develop their own expertise. In addition to the basic courses, professional compulsory courses, professional direction courses, professional elective courses, students should also develop their own expertise and cultivate multi-purpose application-oriented talents. While studying the knowledge of the major, they should also develop their own professional skills, realize the training education system of "one specialty and multiple abilities". To combine their own professional knowledge and professional expertise can broaden their employment range in the process of future employment and effectively protect the transmission of talents in the media industry. In the training process of applied talents of the radio \& TV editing, colleges and universities should also combine the theoretical knowledge and practical ability. If students only have the theoretical knowledge but do not know how to practice it, their working efficiency will be reduced in the future work. Only by depending on the strengthening of the practice section can their application abilities be changed. Fully combine the theoretical knowledge and practice and cultivate students' application skills. The demands of the new era for the radio\&television talents are the key contents of teaching in the undergraduate period of the radio \& TV talents. Under the development background in the new era, talents cultivated by the radio \& TV editing major should be familiar with the national news and the Party's guidelines, always pay attention to the party's policies and regulations, understand the theoretical frontier and technology developments of the television\&radio. Cultivate their artistic cultivation, artistic quality and artistic creation skills of the radio \& TV editing. Cultivate their love for work and dedication attitude. By focusing on the applied talent training model of the radio \& TV editing, cultivate skills in a pertinent manner in the process of learning so that graduates can rapidly enter the social workplace of relevant areas after graduation. The cultivation mode of radio \& TV editing should stick to the ultimate objective of the innovative cultivation of applied talents. The national soft culture is of strategic significance to the development of the country. Some of the historical and cultural image materials need the applied talents of radio \& TV editing. Creation and innovation can improve the 
comprehensive national strength of a country. Cultivating talents is the important direction for the future development of the world. Only by constantly enriching the people's spiritual and cultural world can we unite the culture and strength of a country and nation.

\section{Construction of Cultivation Mode of Applied Talents of radio \& TV editing}

Make clear the ultimate feature of the talent cultivation of the major orientation. The determination of the cultivation objective of applied talents of the radio \& TV editing is influenced by many social factors, such as the development of higher education, development of subject and specialties. It can be determined only by combining these development conditions with the cultivation objectives. "Big major and multiple orientations" is one trend of the setting of higher education majors. According to the specific needs of the market for the media, the employment directions can be divided into three directions: broadcasting and hosting, television program production, audio production. In choosing the radio \& TV editing as the development orientation, students should combine their own interests and future development directions to choose one orientation as the main objective supplemented by the curriculum of other several orientations, so as to ensure students' comprehensive development. To select the direction of employment by combining with their own learning characteristics is conducive to promoting the implementation of the special teaching of the radio \& TV editing and meanwhile cultivating the individuality and diversified development. The future employment directions of the radio and television editing major will be extensive. Students can enter the radio and television stations, or work in the private film and television companies. The publicity departments of the administrative agencies will recruit them. Large-scale enterprises will also recruit them as the publicity and art workers. Therefore, the graduates of the radio \& TV editing majors have wide employment orientations. The curriculum system of the radio \& TV editing majors is very large. According to the different future employment training direction, set different basic courses and professional compulsory courses. While setting the professional direction courses, fully combine the individuality development of students. Carry out the diversified professional elective courses according to the different interests of students and expertise. Conduct the practice module of the radio \& TV major in an all-round way. Different professional knowledge needs the relevant practice modules. The basic courses and elective courses of the major should be in line with each other, so as to play the supporting role and start more comprehensive internship activities.

\section{Set up the Complete Examination \& Evaluation System of Professional Curricula}

The assessment system of the talent training mode should be integrated scientifically. Deeply know about each section of the training system, ensure the cultivation quality of applied talents. Each professional course should set the corresponding regular assessment. The major should set the according internship activities. For the concrete conditions of the internship activities, conduct a comprehensive assessment, set the internship diary and require students to carefully fill out the internship report and internship diary. Teachers assess and score the students according to the completion of the internship report. Set the assessment system in the graduation internship. Set the according internship contents according to the concrete arrangement of learning tasks. For the graduate thesis, students are required to carry out thesis defense, in order to examine the students' mastery of the paper and further confirm students' papers. Conduct according evaluation of their participation in teachers' scientific research activities, encourage students to actively participate in some scientific research projects so as to enable them to fully accumulate working experience and scientific research strength. Carry out the relevant professional qualification examinations, which should be closer to the social needs and enrich the target content of the training. Students gain the appropriate vocational qualifications and vocational skills certificates, which confirms their learning of the professional theoretical knowledge of the radio and TV major. 


\section{Conclusion}

The training mode of applied talents of the radio \& TV editing needs to be adjusted in a comprehensive way, and the training mode of radio \& TV editing should be studied, and the corresponding training specifications and training methods should be set up. In the process of cultivating the applied talents of the radio \& TV editing major, senior talents must have the spirit of innovation and practical ability, and must use the correct ideas as the guiding ideology of the work. While studying the knowledge of the major, they should also develop their own professional skills, regard the cultivation of application skills as a pillar and promote their own development in the future.

\section{References}

[1] Wang Huan. Analysis of Innovative Thinking Cultivation of Radio \& TV Editing U]. Shenzhou, $2013(03)$

[2] Zhang Xingang, Zhou Shiqun. Thinking of Orientation Construction of Radio \& TV Editing Major in Local Colleges and Universities[J]. The Press, 2010 (01)

[3] Gao Yuwei, Zhang Lianjun.Application of Case Teaching Method in Radio \& TV Editing Major of Independent Institutions U]. Introduction Journal of Scientific and Technical Innovation, 2013 (08)

[4] Li Guixia, Zhong Jianling, Wang Lihong.Study on the Construction of Practical Talents Training Model [J]. Education and Occupation, 2009

[5] Qian Guoying, Xu Liqing, Ying Xiong. Higher Education Transformation and Cultivation of Undergraduate Talents [J]. Hangzhou Zhejiang University Press, 2011

[6] Liu Yingchun, Xiong Zhixin. Targeted Positioning of Applied Talent Cultivation and Research of Its Knowledge, Ability and Quality Structure [J]. China University Teaching, 2013 